\title{
Chemical and Biological Investigations of Cerbera odollam Gaertn
}

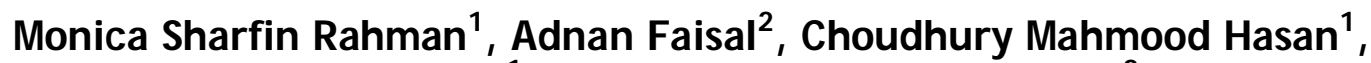 \\ Monira Ahsan ${ }^{1}$ and Mohammad Mehedi Masud ${ }^{2}$ \\ ${ }^{1}$ Department of Pharmaceutical Chemistry, Faculty of Pharmacy, University of Dhaka, \\ Dhaka- 1000, Bangladesh \\ ${ }^{2}$ Uttara Adhunic Medical College, Uttara, Dhaka, Bangladesh
}

(Received: August 24, 2017; Accepted: September 20, 2017; Published (web): December 23, 2017)

\begin{abstract}
The present article describes the isolation and characterization of secondary metabolites from the leaves of Cerbera odollam as well as bioactivities of the crude methanolic extract and its petroleum ether (PE), carbon tetrachloride (CTC), chloroform (CF) and aqueous (AQ) soluble fractions. In this investigation, successive chromatographic separation and purification yielded $\beta$-amyrin (CO-01), lupeol (CO-02), $\beta$-sitostenone (CO-03) and triticusterol (CO-04). The study also indicated the antioxidant, cytotoxic, antimicrobial, membrane stabilizing activities and poor thrombolytic activities. Thus, the present study endeavors to provide scientific basis to establish Cerbera odollam as a potential medicinal plant.
\end{abstract}

Key words: Cerbera odollam, triticusterol, antioxidant activity, cytotoxicity, antimicrobial activity, thrombolytic activity, membrane stabilizing activity.

\section{INTRODUCTION}

To date, plants have always been useful to us not only in the treatment of various diseases, but also as a potential lead for discovering bioactive molecules in drug development process. The scientific exploitation of plants that are traditionally used as folk medicine for pain relief, wound healing and abolishing fevers resulted in the identification of a wide range of compounds and consequently paved the way of new therapies for cancer, hypertension, diabetes and infectious diseases. ${ }^{1}$ A dramatic increase is also observed in last decade in the demand of medicinal plant as new potential source for both traditional and contemporary medicine in both developing and developed countries. ${ }^{2}$ It is estimated that, world's population will be more than 7.5 billion in the next 10 to 15 years. This increase in population will occur

Correspondence to: Mohammad Mehedi Masud

Email: mehedi33@du.ac.bd

Dhaka Univ. J. Pharm. Sci. 16(2): 179-186, 2017 (December) mostly in the southern hemisphere, where approximately $80 \%$ of the population rely on a traditional system of medicine based on herbal drugs for primary healthcare. ${ }^{1}$ Despite such high demand of this traditional medicine, it is observed that only $1 \%$ of them are known by the scientists and accepted for commercial uses. ${ }^{3}$ Therefore, in this article, an attempt has been described which was taken to isolate and characterize the chemical constituents of the medicinal plant Cerbera odollam. In addition, efforts were taken to evaluate the possible biological profiles of the plant.

C. odollam, sometimes called $C$ manghas $\mathrm{L}$, belongs to the poisonous Apocynaceae family. The plant is also known as pong-pong, buta-buta, nyan or yellow-eyed cerbera tree in various regions. ${ }^{4}$ It mainly grows in coastal salt swamps and creeks in south India and also along the river banks in southern and central Vietnam, Cambodia, Sri Lanka, Myanmar and Malaysia. ${ }^{5}$ The seeds have a long history as a 
poison, particularly in Madagascar, due to the presence of highly toxic cardiac glycoside in them. Apart from poisoning, the plant is also used traditionally as emetic, cathartic, in curing hydrophobia and rheumatism. ${ }^{6}$ Previous phytochemical investigations of $C$. odollam showed the presence of triticusterol, 2,6-dihydroxy-4methoxybenzoic acid, 2-hydroxy-4-methoxy-6methyl benzoic acid, ${ }^{7}$ vebioside, deacetyl-tanghinin, neriifolin, tanghinin, monoacetylneriifolin, ${ }^{8}$ and cardenolide glycoside 3 beta-O-(2'-O-acetyl-1thevetosyl)-15(14-->8)-abeo-5 beta-(8R)-14-oxocard-20(22)-enolide (2'-O-acetyl cerleaside A). ${ }^{9}$ Biological activity evaluation also revealed its potential in anticancer, ${ }^{10}$ antinociceptive, antibacterial, diuretic, ${ }^{11}$ cytotoxic, $^{12}$ neuropharmaco$\operatorname{logical}^{6}$ and antioxidant activities ${ }^{7}$ of this plant.

The main objective of the present study was to isolate and characterize secondary metabolites of the leaf of $C$. odollam and evaluation of antioxidant, cytotoxicity, antimicrobial, thrombolytic and membrane stabilizing activities.

\section{MATERIALS AND METHODS}

\section{Chemical investigation}

Collection and preparation of plant material. For the investigation, leaves of the $C$. odollam were collected from the Sunderban area, Bangladesh. Identification was confirmed by an expert taxonomist of Bangladesh National Herbarium (Acc. No. 31302). After collection, the leaves were sun dried for eight days. For better grinding, the leaves were then subjected to oven drying for about 24 hours at considerably low temperature. A high capacity grinding machine was used for crushing the dried leaves into a coarse powder.

Extraction. About $600.0 \mathrm{gm}$ of powdered plant material (leaves) was soaked in about 2.00 liter of methanol in a 4.00 liter capacity amber glass container. It was kept for two weeks with occasional shaking and stirring. At the end of two weeks, the whole mixture was subjected to filtration through cotton plug and then through Whatman No. 1 filter paper. For evaporating the solvent a Buchii Rota evaporator was used at low temperature and pressure to provide about 36.00 gm crude dry extract.

Isolation of chemical constituents. For the initial rapid fractionation, the extract was subjected to vacuum liquid chromatography (VLC). ${ }^{13}$ The whole crude extract was fractionated over silica gel powder (Silica gel $60 \mathrm{H}$ ) by using different solvents of increasing polarities. Initially, $100 \%$ pet ether was used as the solvent system, which was followed by a mixture of pet ether and ethyl acetate and then ultimately $100 \%$ ethyl acetate. At the end, small amount of methanol was also used in combination with ethyl acetate for better separation of the crude extract. A total of 23 fractions (each $100 \mathrm{ml}$ ) were eluted.

For the assessment, elutes were spotted on Thin Layer Chromatography (TLC) plates . Based on the TLC plate behavior, some of the fractions were then subjected to gel permeation chromatography over lipophilic Sephadex (LH-20).

A total of 121 fractions, each $100 \mathrm{ml}$ were collected. Then the fractions were examined using TLC and on the TLC features, potential fractions were selected for further purification. At this stage, the fractions were subjected to TLC over silica gel $\mathrm{PF}_{254}$ and the developed plates were then examined under UV lamp (both at $254 \mathrm{~nm}$ and $366 \mathrm{~nm}$ ) and also by spraying the plate with vanillin-sulfuric acid reagent followed by heating at $110^{\circ} \mathrm{C}$ for few minutes to locate promising spots. Further purification of fractions 11, 101, 02 and 107 by preparative TLC provided $\mathrm{CO}-04, \mathrm{CO}-01, \mathrm{CO}-02$ and $\mathrm{CO}-03$ respectively.

NMR spectroscopy. A Brucker (400 MHz) instrument was used for recording ${ }^{1} \mathrm{H}$ NMR and ${ }^{1} \mathrm{H}$ ${ }^{1} \mathrm{H}$ COSY spectra in $\mathrm{CDCl}_{3}$ and the chemical shift values were determined with respect to the residual non-deuterated solvent signal.

Biological investigation of Cerbera odollam. For biological investigation, the crude methanolic extract of $C$. odollam was subjected to solventsolvent partitioning using the protocol designed by Kupchan and modified by Van Wagenen et al. ${ }^{14}$ According to this method, about $5 \mathrm{mg}$ crude extract 
was dissolved in $10 \%$ aqueous methanol. Then the methanolic solution was extracted with petroleum ether followed by carbon tetra chloride and finally with chloroform. Then each of the fractions were subjected to biological investigations such as evaluation of antioxidant, cytotoxic, antimicrobial, thrombolytic and membrane stabilizing activities.

CO-01(ß-amyrin): White amorphous solid; ${ }^{1} \mathrm{H}$ NMR (400 MHz, $\left.\mathrm{CDCl}_{3}\right), \delta 0.77$ (3H, s, H-24), 0.78 (3H, s, H-28), 0.85 (6H, s, H-29, H-30), 0.92 (3H, s, H-25), 0.95 (3H, s, H-23), 0.98 (3H, s, H-26), 1.23 (3H, s, H-27), 3.21 (1H, dd, J= 10.8, 5.2 Hz, H-3), $5.11(1 \mathrm{H}, \mathrm{dd}$, $J=3,6 \mathrm{~Hz}, \mathrm{H}-12)$.

CO-02 (Lupeol): White amorphous solid; ${ }^{1} \mathrm{H}$ NMR (400 MHz, $\left.\mathrm{CDCl}_{3}\right), \delta 0.77$ (3H, s, H-28), 0.78 (3H, s, H-23), $0.81(3 \mathrm{H}, \mathrm{s}, \mathrm{H}-24)$, 0.94 (3H, s, H-25), 0.99 (3H, s, H-26), 1.05 (3H, s, H-27), 1.66 (3H, s, H-30), 3.20 (1H, m, H-3), 4.54 (1H, br, s, H-29), 4.66 (1H, br, s, H-29).

CO-03 (ק-sitostenone): White amorphous solid; ${ }^{1} \mathrm{H}$ NMR $\left(400 \mathrm{MHz}, \mathrm{CDCl}_{3}\right), \delta 0.67\left(3 \mathrm{H}, \mathrm{s}, \mathrm{H}_{3}-18\right), 0.80\left(3 \mathrm{H}, \mathrm{d}, J=6.8 \mathrm{~Hz}, \mathrm{H}_{3}-27\right)$, $0.82\left(3 \mathrm{H}, \mathrm{d}, J=6.4 \mathrm{~Hz}, \mathrm{H}_{3}-26\right), 0.82\left(3 \mathrm{H}, \mathrm{t}, J=7.6 \mathrm{~Hz}, \mathrm{H}_{3}-29\right), 0.90$ (3H, d, $\left.J=6.4 \mathrm{~Hz}, \mathrm{H}_{3}-21\right), 1.16\left(3 \mathrm{H}, \mathrm{s}, \mathrm{H}_{3}-19\right), 5.70$ (1H, s, H-4).

CO-04 (triticusterol): 0.89 (3H, s, H-1), 0.91 (3H, d, $J=6.4 \mathrm{~Hz}, \mathrm{H}-7), 0.98$ (3H, s, H-8), 0.98 (3H, d, $J=6.4 \mathrm{~Hz}, \mathrm{H}-9), 1.01$ (3H, d, $J=6.4$ Hz, H-11), 1.02 (3H, d, J=6.4 Hz, H-16), 3.20 (1H, m, H-18), 4.69, 4.64 (2H, s, H-24).

Evaluation of antioxidant activity. For the evaluation of antioxidant activity, DPPH assay, designed by Brand-Williams et al. ${ }^{15}$ was selected for the current investigation. In this investigation, evaluation of scavenging activities of the stable 1, 1diphenyl-2-picrylhydrazyl (DPPH) was used as the basis for assessing the antioxidant activities of the test samples taking butylated hydroxyl toluene (BHT) as the reference standard.

Evaluation of cytotoxicity. Brine shrimp lethality test was selected for screening cytotoxic activity of the plant. ${ }^{16}$ In this investigation, DMSO (Dimethyl sulfoxide, Bioreagent, for molecular biology: Sigma-Aldrich, India) was used as solvent and negative control, whereas anticancer drug vincristine sulphate (Techno Drugs Ltd., Bangladesh), was used as positive control. Statistical analysis of concentration-mortality data was performed by using linear regression by using a simple IBM-PC program.

Screening of antimicrobial activity. For the current study, the method described by Bauer et al ${ }^{17}$ was selected for screening antimicrobial activity against six gram positive bacteria and eight gram negative bacteria. The strains of bacteria were collected as pure culture from Institute of Nutrition and Food Science, University of Dhaka. Sterile blank discs and standard antibiotic discs (Ciprofloxacine 30 $\mu \mathrm{g} / \mathrm{disc})$ were as negative and positive controls respectively. The test samples were loaded on the discs at a concentration of $400.0 \mu \mathrm{g} / \mathrm{disc}$. The antimicrobial activity of the test samples were than evaluated by measuring the zone of inhibition with a digital slide calipers. ${ }^{17,18}$

Evaluation of thrombolytic activity. Thrombolytic activity of the test samples were evaluated by following established protocol. ${ }^{19}$ Streptokinase (SK) was used as a standard for this investigation. For the preparation of positive control, commercially available lyophilized Altepase (Streptokinase) Eppendorf tube of 15, 00, 000 I.U. was collected from Beacon Pharmaceuticals Ltd, Bangladesh. Distilled water was used in the investigation as negative control.

Evaluation of membrane stabilizing activity. Membrane stabilizing activity of methanolic fraction of $C$. odollam leaf extract as well as other fractions of it was evaluated by following previously described method. ${ }^{20}$

\section{RESULTS AND DISCUSSION}

Chemical investigation of Cerbera odollam. The methanolic extract of the leaves of $C$ odollam 
(Family: Apocynaceae) was investigated for isolation of the potent secondary metabolites from this plant. Successive chromatographic separation and purification yielded a total of ten compounds. Among them, the structures of four compounds were solved as $\beta$-amyrin, lupeol, $\beta$-sitostenone and triticusterol (Figure 1). Except triticusterol, this is the frist report of isolation of $\beta$-amyrin, lupeol and $\beta$-sitosterol from this plant.

The ${ }^{1} \mathrm{H}$ NMR spectrum (400 $\mathrm{MHz}, \mathrm{CDCl}_{3}$ ) of compound $\mathrm{CO}-01$ showed the presence of eight methyl singlets at $\delta 0.78(3 \mathrm{H}, \mathrm{s}, \mathrm{H}-28), 1.23(3 \mathrm{H}, \mathrm{s}$, H-27), 0.98 (3H, s, H-26), 0.92 (3H, s, H-25), 0.77 (3H, s, H-24), 0.95 (3H, s, H-23), 0.85 (6H, s, H-29 and $\mathrm{H}-30$ ). This suggested $\mathrm{CO}-01$ to be a pentacyclic triterpenoid. A characteristic double doublet of one intensity at $\delta 5.11(1 \mathrm{H}, \mathrm{t}, J=3.6 \mathrm{~Hz})$ was assigned to $\mathrm{H}-12$, on an olean-12-ene skeleton. An oxymethine proton at $\delta 3.21(1 \mathrm{H}, \mathrm{dd}, J=10.8,5.2 \mathrm{~Hz})$ could be assigned to $\mathrm{H}-3$. The coupling constant of this methane proton indicated that the hydroxyl function must be in axial position. The above features were similar to the ones reported for $\beta$-amyrin. On this basis, CO-01 was identified as $\beta$-amyrin. ${ }^{21}$

The ${ }^{1} \mathrm{H}$ NMR spectrum $\left(400 \mathrm{MHz}, \mathrm{CDCl}_{3}\right.$ ) of compound CO-02 displayed signals for a major and a minor compound. However, careful analysis allowed us to identify the major compound as lupeol. Two olefinic protons at $\delta_{\mathrm{H}} 4.66$ and $4.54(1 \mathrm{H}$, br. s each), a vinylic methyl at $\delta 1.66(3 \mathrm{H}, \mathrm{s}, \mathrm{H}-30)$ and six tertiary methyl signals at $\delta 1.05(3 \mathrm{H}, \mathrm{s}, \mathrm{H}-27), 0.99(3 \mathrm{H}, \mathrm{s}, \mathrm{H}-$ 26), 0.93 (3H, s, H-25), 0.81 (3H, s, H-24), 0.78 (3H, $\mathrm{s}, \mathrm{H}-23)$ and $0.77(3 \mathrm{H}, \mathrm{s}, \mathrm{H}-28)$. Further the spectrum showed an oxymethine proton signal at $\delta 3.20(1 \mathrm{H}$, $\mathrm{m})$, attributable to $\mathrm{H}-3$. On this basis, $\mathrm{CO}-02$ indicates the presence of lupeol. ${ }^{22}$

The ${ }^{1} \mathrm{H}$ NMR (400 $\mathrm{MHz}, \mathrm{CDCl}_{3}$ ) spectrum of compound CO-03 displayed a broad singlet for an olefinic proton at $\delta 5.70(\mathrm{H}-4)$. The spectrum also revealed singlets at $\delta 1.16$ and 0.67 (each $3 \mathrm{H}, \mathrm{s}$ ) assignable to two tertiary methyl groups at $\mathrm{C}-10\left(\mathrm{H}_{3}-\right.$ 19) and $\mathrm{C}-13\left(\mathrm{H}_{3}-18\right)$, respectively. The doublets at $\delta 0.90(J=6.4 \mathrm{~Hz}), 0.82(J=6.4 \mathrm{~Hz})$ and $0.80(J=6.4$ $\mathrm{Hz})$ of three proton intensity each were demonstrative of methyl groups at C-20 $\left(\mathrm{H}_{3}-21\right)$ and $\mathrm{C}-25\left(\mathrm{H}_{3}-26\right.$, $\left.\mathrm{H}_{3}-27\right)$, respectively. A three proton triplet $(\mathrm{J}=7.6$ $\mathrm{Hz})$ at $\delta_{\mathrm{H}} 0.82$ was observed for another methyl group at $\mathrm{C}-28\left(\mathrm{H}_{3}-29\right)$. On this basis, the structure of the compound $\mathrm{CO}-03$ was resolved as $\beta$-sitostenone, an isomer of $\beta$-sitosterone. The identity of compound $\mathrm{CO}-03$ as $\beta$-sitostenone was confirmed by comparison of its spectral data with published values. ${ }^{23}$

The ${ }^{1} \mathrm{H}$ NMR spectrum $\left(400 \mathrm{MHz}, \mathrm{CDCl}_{3}\right)$ of compound CO-04 also showed signals for a major and a minor compound. However, careful analysis allowed us to identify the major compound as triticustrerol. Two signals at $\delta_{=} 0.89$ and $0.97 \mathrm{ppm}$ for angular methyl groups at $\mathrm{C}-13$ and $\mathrm{C}-10$, respectively. It also revealed four doublets centered at $\delta 0.92(3 \mathrm{H}, \mathrm{d}, J=6.4 \mathrm{~Hz}) ; 0.98(3 \mathrm{H}, \mathrm{d}, J=6.4 \mathrm{~Hz})$; $1.01(3 \mathrm{H}, \mathrm{d}, J=6.4 \mathrm{~Hz})$ and $1.02(3 \mathrm{H}, \mathrm{d}, J=6.4 \mathrm{~Hz})$ which could be attributed to the methyl substituents at C-20, C-4, and C-25 respectively. The spectrum further demonstrated a one proton multiplet at $\delta 3.2$, indicative of $\mathrm{H}_{\alpha}-3$ of the steroid nucleus. Two downfield singlets were appeared at $\delta 4.64$ and 4.69 ppm suggesting the presence of two exomethylene protons $\left(\mathrm{H}_{2}-24^{1}\right)$. These features are in close agreement to those observed for triticustrerol. ${ }^{7}$

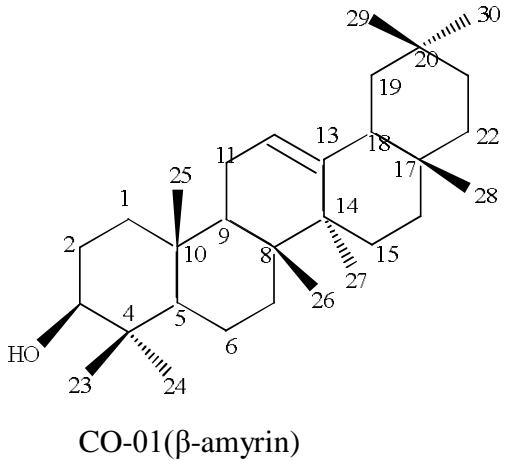

CO-01( $\beta$-amyrin)

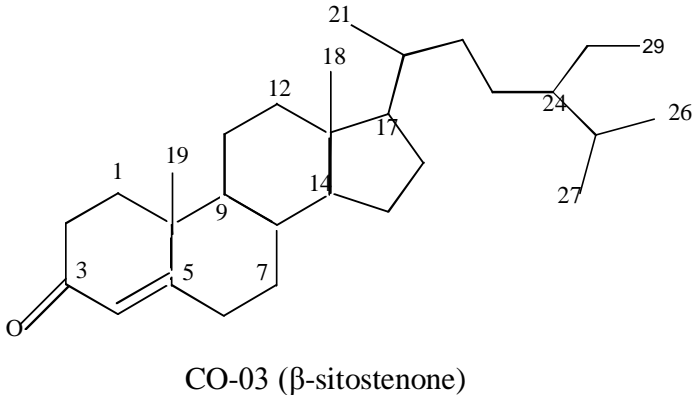

CO-03 ( $\beta$-sitostenone) 


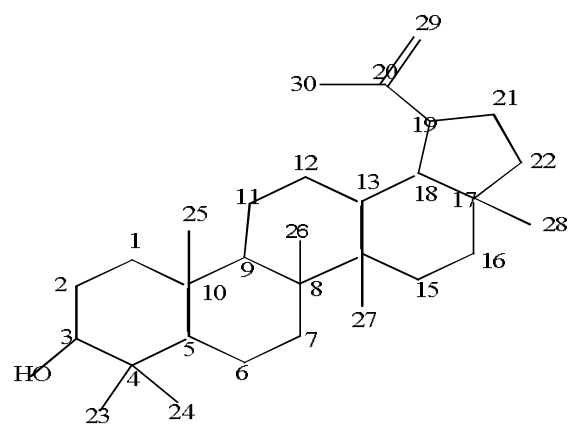

CO-02 (Lupeol)

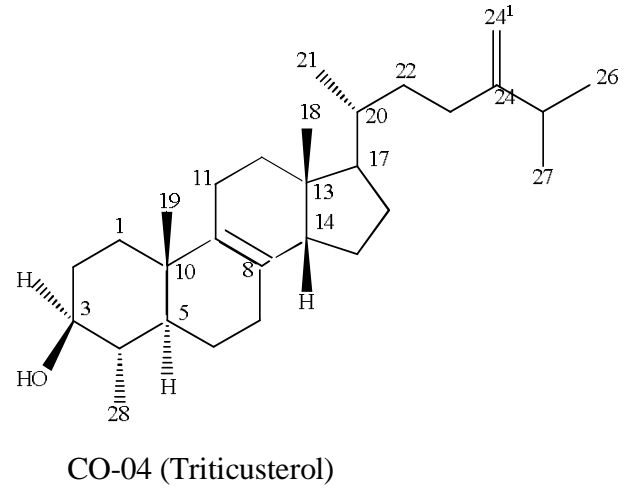

CO-04 (Triticusterol)

Figure 1. Structures of CO-01, CO-02, CO-03 and CO-04.

\section{Biological investigation of Cerbera odollam}

Evaluation of antioxidant activity. The methanolic extract of $C$. odollam and its different organic fractions were subjected for antioxidant activity evaluation by the method suggested by Brand-willium et al. ${ }^{15}$ Here, BHT was used as reference for which $23.50 \pm 1.00$ of $\mathrm{IC}_{50}$ value was obtained. In the evaluation, chloroform fraction of the plant showed the least inhibitory concentration of all the fractions with $\mathrm{IC}_{50}$ value of $40.00 \pm 1.00 \mu \mathrm{g} / \mathrm{ml}$, then carbon tetrachloride fraction and the methanolic extract showed the significant free radical scavenging activity with $\mathrm{IC}_{50}$ value of $72.01 \pm 1.00 \mu \mathrm{g} / \mathrm{ml}$ and $75.02 \pm 1.00 \mu \mathrm{g} / \mathrm{ml}$, respectively. On the other hand, less significant activity was observed for non-polar fractions (Petroleum ether and aqueous fractions) (Figure 2). Comparing the $\mathrm{IC}_{50}$ values obtained from the polar fractions with the reference, it may be suggested that the plant may act as a potential source of antioxidant.

Evaluation of cytotoxicity. In the investigation, the lethal concentrations $\mathrm{LC}_{50}$ of the test samples were calculated after 24 hours of observation by plotting the percentage of the shrimp died against the logarithm of sample concentration. The best fit line was taken from the curve by means of regression analysis. In this study, vincristine sulfate (VS) was used as a positive control for which $\mathrm{LC}_{50}$ was found to be $0.37 \mu \mathrm{g} / \mathrm{ml}$. The $\mathrm{LC}_{50}$ values of PEF, CTCF, $\mathrm{CF}, \mathrm{MF} \& \mathrm{AQF}$ were found to be $12.80 \mu \mathrm{g} / \mathrm{ml}, 8.49$ $\mu \mathrm{g} / \mathrm{ml}, 7.67 \mu \mathrm{g} / \mathrm{ml}, 10.77 \mu \mathrm{g} / \mathrm{ml}$, and $6.28 \mu \mathrm{g} / \mathrm{ml}$ respectively (Figure 3 ). Comparing these values with the value obtained from standard, it was observed that all the fractions were quite lethal for the brine shrimp nauplii. From this observation, it may be proposed that this plant might act as a potential source of anticancer agents.

Antimicrobial screening. In the microbiological investigation, Ciprofloxacine was used as standard. The methanolic extract fraction (MEF) of $C$. odollam demonstrated moderate activity (zone of inhibition 8 $\mathrm{mm}$ ) against Bacillus megaterium \& Shigella flexneri, Pet ether fraction (PEF) was moderately active (zone of inhition between 7-8 $\mathrm{mm}$ ) against Bacillus cereus \& Shigella sonni. Carbon tetrachloride fraction (CTCF) showed moderate activity (zone of inhibition between 7-9 mm) against maximum bacterias: Bacillus subtilis, Bacillus megaterium, Bacillus cereus, Staphylococus aureus \& Sacina lutea. Chloroform fraction (CF) showed moderate activity (zone of inhibition between 7-8 $\mathrm{mm}$ ) against Bacillus subtilis, Bacillus polymyxa, kleb Species \& aqueous fraction (AQF) demonstrated moderate activity (zone of inhibition between $7 \mathrm{~mm}$ ) against Bacillus subtilis. It can be predicted from the observations that the plant is primarily active against gram positive bacteria. Thus, it may be suggested that the plant might act as a potential source of antimicrobial agents. 


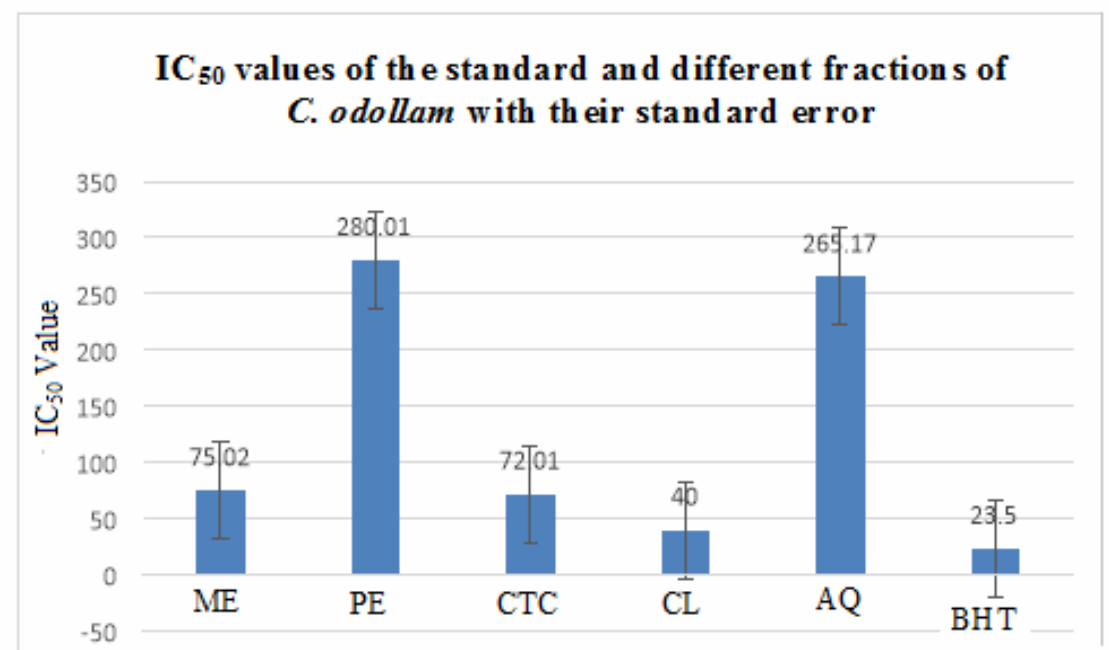

Figure 2. $\mathrm{IC}_{50}$ values of the standard and different fractions of $C$. odollam $(\mathrm{ME}=$ Methanolic Extract of the leaf, $\mathrm{PE}=$ Pet-ether fraction of the leaf, $\mathrm{CTC}=$ Carbon tetrachloride fraction of the leaf, $\mathrm{CL}=$ Chloroform fraction of the leaf, $\mathrm{AQ}=$ Aqueous fraction of the leaf, BHT $=$ tert- butyl-1-hydroxytoluene)

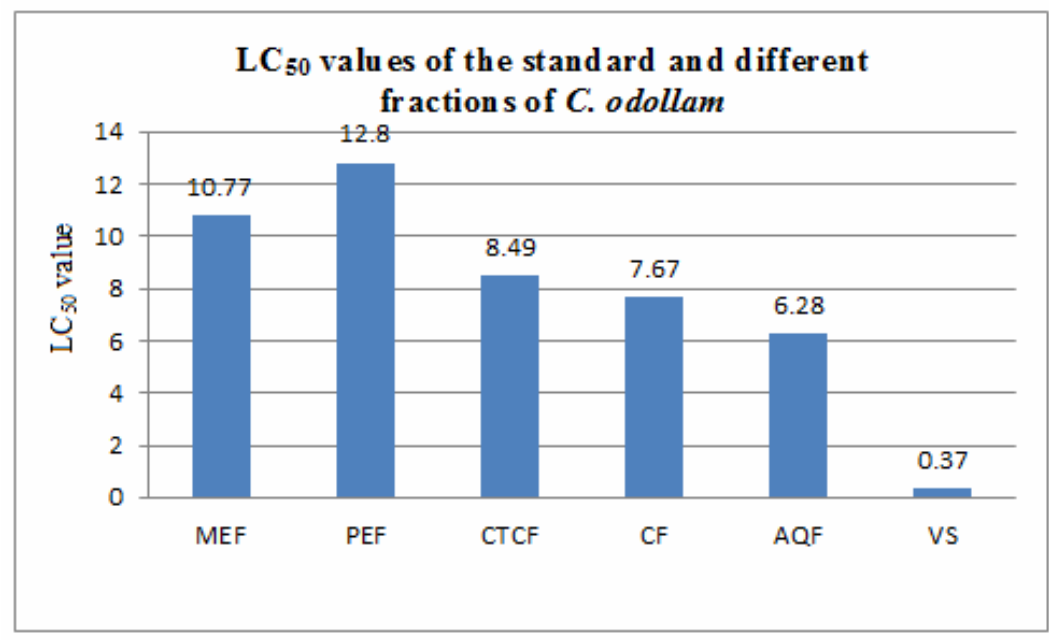

\begin{tabular}{|c|c|}
\hline Test simples & Regression line \\
\hline MEF & $\mathrm{y}=26.01 \mathrm{x}+23.15$ \\
\hline PEF & $\mathrm{y}=25.29 \mathrm{x}+21.99$ \\
\hline CTCF & $\mathrm{y}=27.50 \mathrm{x}+24.44$ \\
\hline CF & $\mathrm{y}=30.40 \mathrm{x}+23.12$ \\
\hline AQF & $\mathrm{y}=25.73 \mathrm{x}+29.47$ \\
\hline VS & $\mathrm{y}=31.40 \mathrm{x}+63.68$ \\
\hline
\end{tabular}

Figure 3. $\mathrm{LC}_{50}$ values of the standard and different fractions of $C$. odollam $(\mathrm{MEF}=$ Methanolic Extract of the leaf, $\mathrm{PEF}=\mathrm{Pet}-\mathrm{ether}$ fraction of the leaf, $\mathrm{CTCF}=$ Carbon tetrachloride fraction of the leaf, $\mathrm{CF}=$ Chloroform fraction of the leaf, $\mathrm{AQF}=\mathrm{Aqueous}$ fraction of the leaf, VS= Vincristine sulphate)

Thrombolytic activity. In thrombolytic activity evaluation, the standard Streptokinase (SK), that was used as a positive control showed $65.50 \pm 1.00 \%$ lysis of clot. On the other hand, distilled water was treated as negative control which exhibited a negligible percentage of lysis of clot $(8.20 \pm 1.00 \%)$. The mean difference in clot lysis percentage between positive and negative control was found very significant. In this study, the methanolic extract of $C$. odollam (MESF) exhibited thrombolytic activity $8.88 \pm$ $1.00 \%$, the petroleum ether fraction (PEF) exhibited
$0.41+1.00 \%$, carbon tetrachloride soluble fraction (CTCF) exhibited $14.10 \pm 1.00 \%$, chloroform fraction $(\mathrm{CF})$ exhibited $11.80 \pm 1.00 \%$ and the aqueous soluble fraction (AQF) exhibited $8.34 \pm$ $1.00 \%$ thrombolytic activity (Figure 4). By comparing the test results with the standard agents, it may be proposed that at higher dose, this plant might act as a potential thrombolytic agent.

Evaluation of membrane stabilizing activity. The methanolic extract and its different fractionates of leaves of $C$. odollam were effective in the 
membrane stabilizing activity as the extractives prevented the lysis of erythrocytes induced by hypotonic solution. The petroleum ether fraction (PEF) inhibited 58.63\%, methanolic extract fraction (MEF) inhibited $55.43 \%$, chloroform fraction (CF) inhibited $47.03 \%$, carbon tetrachloride fraction
(CTCF) inhibited $42.42 \%$ and aqueous fraction inhibited (AQF) $36.87 \%$ of haemolysis of RBC. For membrane stabilizing activity Acetyl Salicyalic Acid was used as standard drug for which $71.90 \%$ inhibition of haemolysis was observed at normal condition.

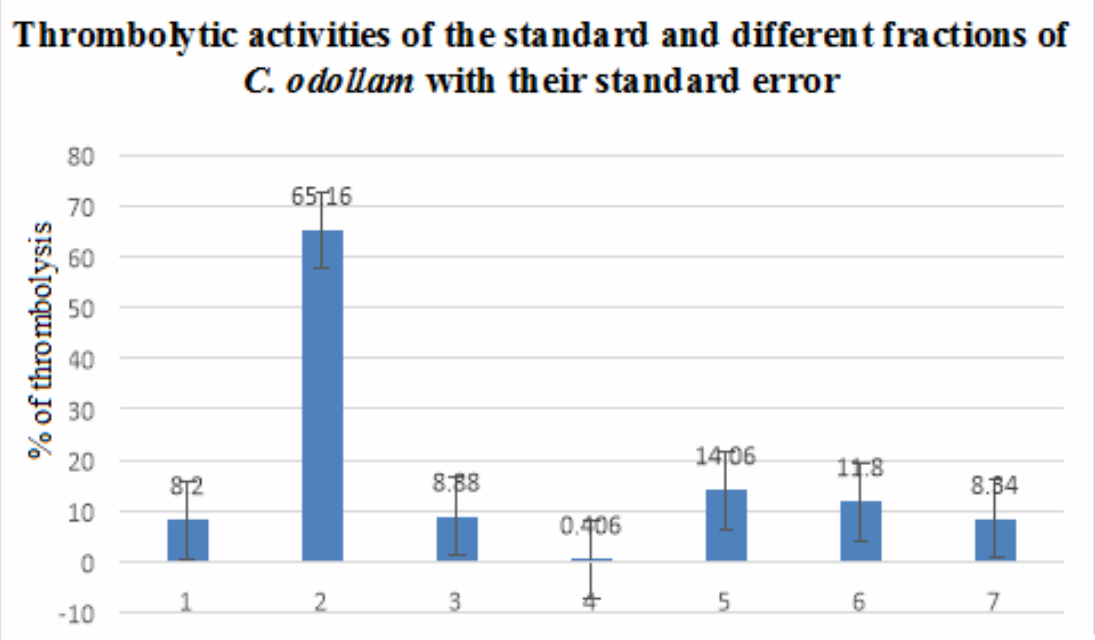

Figure 4. Thrombolytic activity of the standard and different fractions of $C$. odollam $(1=$ Blank, $2=$ Streptokinase, $3=$ Methanolic extract of the leaf, $4=$ Pet ether fraction of the leaf, $5=$ Carbon tetrachloride fraction of the leaf, $6=$ Chloroform fraction of the leaf, $7=$ Aqueous fraction of the leaf)

But, the methanolic extract and its different fractionates of leaves of $C$. odollam were mildly effective in the heat induced membrane stabilizing activity. In the experiment, the petroleum ether fraction (PEF) inhibited $38.74 \%$, metahanolic extract (ME) inhibited $35.41 \%$, chloroform fraction (CF) inhibited $23.76 \%$, carbon tetrachloride fraction (CTCF) inhibited $23.34 \%$ and aqueous soluble partitionate inhibited (AQSF) $14.81 \%$ of haemolysis of RBC. For membrane stabilizing activity Acetyl Salicyalic Acid was used as standard drug that exhibited $42.20 \%$ inhibition of haemolysis at normal condition. Comparing the test results with the standard, the plant concerned might be suggested to be a potential source of anti-inflammatory drug.

\section{CONCLUSION}

Successive chromatographic separation and purification of methanolic extract of the leaves of $C$. odollam yielded a total of ten compounds. Among them the structures of four compounds were elucidated, viz., $\beta$-amyrin, lupeol, $\beta$-sitostenone and triticusterol. In free radical scavenging assay, chloroform soluble fraction showed the least inhibitory concentration among all the fractions with $\mathrm{IC}_{50}$ value of $40.00 \mu \mathrm{g} / \mathrm{ml}$. In brine shrimp lethality bioassay, all the fractions showed good cytotoxic activity. In the microbiological investigation, the carbon tetrachloride soluble fraction of methanolic extract demonstrated mild activity against most of the bacteria with zone of inhibition 7-8 $\mathrm{mm}$. During evaluation of thrombolytic property, the extractives of $C$. odollam showed very poor clot lysis activity as compared to the standard substance, streptokinase (SK). Only the carbon tetrachloride fraction showed little thrombolytic activity (14.06\%). In membrane stabilizing activity assay, the methanolic extract of leaves of C. odollam at a concentration of 1.00 $\mathrm{mg} / \mathrm{ml}$, moderately protected the lysis of human erythrocyte membrane induced by hypotonic solution 
and heat, as compared to the standard acetyl salicylic acid $(0.10 \mathrm{mg} / \mathrm{ml})$. Due to the presence of medicinally important secondary metabolites, $C$. odollam has significant biological importance. So, further study concerning this plant, there might be a new pathway for the mitigation of human sufferings.

\section{REFERENCES}

1. Ifeoma, O. and Oluwakanyinsola, S. 2013. Screening of herbal medicines for potential toxicities. New insights into toxicity and drug testing. INTECH. 63-88.

2. Rahman, M., Khatun, A., Islam M.M., Akter, M.N., Chowdhury, S.A., Khan, M.A.A., Shahid, M.I.Z and Rahman, A.A. 2013. Evaluation of antimicrobial, cytotoxic, thrombolytic, diuretic roperties and total phenolic content of Cinnamomium tamala. Int. J. Green Pharm. 7, 236-243.

3. Aguilar, G. 2001. Access to genetic resources and protection of traditional knowledge in the territories of indigenous peoples. Environ. Sci. Policy. 4, 241-256.

4. Gaillard, Y., Krishnamoorthy, A. and Bevalot, F. 2004. Cerberaodollam: a 'suicide tree' and cause of death in the state of Kerala, Ind. J. Ethnopharmacol. 95, 123-6.

5. Olsen, S.C. and Randerson, J.T. 2004. Differences between surface and column atmospheric $\mathrm{CO}_{2}$ and implications for carbon cycle research. J. Geophys. Res. 109, D02301, doi:10. 1029/2003JD003968.

6. Ahmed, F., Amin, R., Shahid, IZ. and Sobhani, M.M.E. 2008. Antibacterial, cytotoxic and Neuropharmacological activities of cerbera odollam seeds. Oriental Pharma. and Experimental Med. 8, 323-328.

7. Hasan, C.M., Kuddus, M.R., Rumi, F. and Masud, M.M. 2011. Phytochemical screening and antioxidant activity studies of cerbera odollam gaertn. Int. J. Pharma. and Bio. Sci. 2, ISSN 0975-6299.

8. Bisset, N.G. 1961. Cardiac glycosides, apocynaceae: A preliminary paper chromatographic study of the glycosides from some species of Cerbera L. including Tanghiniab Thouars. Annales Bogorienses. Vol. IV, Part 2.

9. Laphookhieo, S., Cheenpracha, S., Karalai, C., Chantrapromma, S., Rat-a-Pa, Y., Ponglimanont, C. and Chantrapromma, K. 2004. Cytotoxic Cardenolide Glycoside From the seeds of Cerbera odollam. Phytochemistry. 65, 507-10.

10. Syarifah, M.M.S., Nurhanan, M.Y., Hafiz J.M., Ilham, A.M., Getha, K., Asiah, O., Norhayati, I., Sahira, H.L. and Suryani, S.A. 2011. Potential anticancer compound from Cerbera Odollam. J. Tropical Forest Sci. 23, 89-96.
11. Rahman, M.A., Paul, P. and Rahman, A.A. 2011. Antinoneceptive, antibacterial and diuretic activities of Cerbera odollam gaertn roots. Res. J. Pharm. Biological and Chem. Sci. 2, Page No. 16.

12. Rahman, M.S., Shetu, H.J., Sukul, A. and Rahman, I. 2015. Phytochemical and Biological evaluation of albizia richardiana benth, Fabaceae family. World J. Pharm. Res. 4, 168-176.

13. Pelletier, S.W., H.P. Chokshi, H.K. and Desai 1986. Separation of diterpenoid mixtures using vaccum liquid chromatography. J. Nat. Prod. 49, 892-900.

14. Van, W.B.C., Larsen, R., Cardellina, J.H.I.I., Ran, D.D., Lidert, Z.C. and Swithenbank, C. 1993. Ulosantoin, a potent insecticide from the sponge ulosaruetzleri. J. Org. Chem. 58, 335-337.

15. Brand-willium, W., Cuvelier, M.E. and Bersetc, 1995. Use of free radical method to evaluate antioxidant activity. Lebensm Wiss Technol. 28, 25-30.

16. Meyer, B.N., Ferringni, N.R., Paum, J.E., Lacobsen, L.B. and Nichols ,D.E. 1982. Drug in of j. 31, 516-554.

17. Bauer, A.W., Kirby, W.M.M., Sherris, J.C. and Truck, M. 1966. Antibiotic susceptibility testing by a standardized single disc method. Am J. Clin. Pathol. 45, 493-496.

18. Barry, A.L. 1976. Principle and practice of microbiology. Lea and Fabager, Philadelphia. $3^{\text {rd }}$ ed. 44, 493-496.

19. Rahman, M.H. 2013. A study on exploration of ethnobotanical knowledge of rural community in Bangladesh: Basis for biodiversity conservation. ISRN Biodiversity. Volume 2013. Article ID 369138.

20. Shinde, U.A., Phadke, A.S., Nair, A.M., Mungantiwar, A.A., Dikshit, V.J. and Saraf, V.O. 1999. Membrane stabilizing activity- a possible mechanism of action for the antiinflammatory activity of Cedrus deodara wood oil. Fitoterapia. 70, 251-257.

21. Vazquez, L.H., Palazon, J. and Ocana, A.N. 2012. The pentacyclic triterpenes $\alpha, \beta$-amyrins: A Review of sources and biological ativities. Phytochemical- A global perspective of their role in nutrition and health, In. Tech. Pg. 487-50.

22. Jain, P.S. and Bari, SB 2010. Isolation of lupeol, stigmasterol and campesterol from petroleum ether extract of woody stem of wrightia tinctoria. Asian J. of Plant Sci. ISSN 1682-3974.

23. Ara, K., Rahman, M.S., Rahman, A.H.M.M., Hasan, C.M. and Rashid, M.R. 2009. Terpenoids and Coumarin from Bursera serrata wall. Dhaka Univ. J. Pharm. Sci. 8, 107-110. 